Williams, R. J. (1946). The Human Frontier. New York: Harcourt, Brace and Co.

Williams, R. J. (1947). Quart. F. Stud. Alc. 7, 567.

Williams, R. J. (1950). Nutr. Rev. 8, 257.

Williams, R. J., Beerstecher, E. Jr. \& Berry, L. J. (1950). Lancet, 258, 287.

Wokes, F., Badenoch, J. \& Sinclair, H. M. (1955). Voeding, 16, 590.

Woolf, L. I., Griffiths, R. \& Moncrieff, A. (1955). Brit. med. F. i, 57.

Wortis, H., Bueding, E., Stein, M. H. \& Jolliffe, N., (1942). Arch. Neurol. Psychiat. Chicago, 47, 2 г.

Yudkin, S. (1941). Lancet, 241, 787.

\title{
Some Traditional Alcoholic Beverages and their Importance in Indigenous African Communities
}

\author{
By B. S. Platt, Human Nutrition Research Unit, Medical Research Council \\ Laboratories, Holly Hill, London, N.W.3
}

Fermented honey drinks may have been the earliest alcoholic beverages known to man and the discovery of them has been attributed to the Hamites (Seyffert, I930). Another hypothesis of the origin of alcoholic liquors is that they were first encountered when wild fruits were stored in clay-lined holes in the ground (Renard, 1929). If beer was not in fact originally brewed by man in Africa, some alcoholic fermentations were developed on that continent. According to the mythology of the Egyptians, their first queen, Isis, discovered wheat and barley growing wild and king Osiris devised means of cultivating them. Osiris is reputed to have introduced the vine from his native country, probably Syria or Palestine, taught its cultivation and the making of wine and the brewing of beer, and, ultimately, he toured the rest of the inhabited earth, which included Ethiopia, teaching mankind how to sow wheat and barley, how to cultivate the vine, and how to enjoy their fruits. One interpretation of this Egyptian tradition is that the knowledge of the cultivation of wheat, barley and the vine, and of the making of beer and wine, was introduced into Egypt by people coming from Syria or Palestine at a very early period-long before the first dynasty, which began about 3400 B.C.; the knowledge of these arts of civilization later spread to India, Europe and Ethiopia. The mountainous part of East Africa, chiefly Abyssinia, has been postulated (Vavilov, 193I) as one of seven fundamental independent centres of the origin of cultivated plants: in this instance, of wheat, barley, sorghum and coffee. There is no archaeological support for this postulate. Evidence exists, however, that between 6000 and 5000 B.C. the Fayum folk, a late Stone Age people living in the Nile valley, cultivated barley of a kind similar to that still grown in Egypt. Although the earliest history of alcoholic fermentation is not known, it does seem likely that in Africa it is a process of considerable antiquity.

There are five main groups of African alcoholic beverages: fermented honey water; fermented fruits and juices; fermented sap from various species of palm and a bamboo*; drinks made from milk, and the beers. All of these have more or less

- The Oxytenanthera braunii Pilger (Greenway, 1945-6). 
familiar equivalents in mead, cider, fermented birch sap, fermented mare's milk (koumiss) and old-fashioned ales.

An account of the fermentation of honey comes from Ethiopia (Beckingham \& Huntingford, 1954), and was written in the early part of the 17 th century:

'Five or six parts of water and one of honey are put into a pot with a handful of toasted barley which makes it ferment. Afterwards they add some morsels of a certain wood they call Sado*, which draws out the sweetness and in five or six days it is ready to drink. It had not the taste of our grape wine, but its wholesomeness undoubtedly gives it an advantage. These people have one great vice, which is that they are much addicted to wine. They do not drink while eating, but when the table is cleared the caloes $\dagger$ are brought into the house and neighbours or friends assemble. In noblemen's houses and in the Emperor's many guests are always invited. There is no conversation without the wine circulating and being drunk in turns until either they are laid out on the spot or else withdraw so much warmed up that they cannot easily find the door. They achieve this by drinking to such excess that no one knows how they can hold so much. The wine is really very mild and if it were drunk in moderation no harm could be done'.

The Abyssinian says, 'You must plant first and then water'; therefore nobody drinks till he has finished eating. An even earlier account of the preparation of wine from honey is found in a record of a Portuguese visit to the west coast of Africa (Monod, da Mota \& Mauny, r95I). It says that the people took honey with its wax and mixed one part of honey to three parts of water. The mixture was kept in closed pots or calabashes and left in the sun or near a fire to keep warm for I2I 5 days; the pots were then opened and the wax, which had come to the top, was removed. The wine was said to have a pleasing taste.

The fruits of many bushes and trees $\ddagger$ are used in the preparation of fermented drinks, but although this practice is widespread the products are by no means as important as those in the other categories. A variety of beverages including several made from fruits are described by Earthy (1933).

Various species of palm§ are tapped for sap which is fermented. The method of tapping the palms is described for South East Africa by Junod (I927), for Nigeria by Mboto (1933) and for the Gambia by Walters \& Smith (1952). In some areas of Africa palm wine is as important in society-for working parties as well as for ceremonial and convivial occasions - as are the 'beers'. In one part of Nigeria in a survey of a number of families totalling nearly 200 persons the average consumption of palm wine throughout the year was $167 \mathrm{~g} /$ head/day; $12 \mathrm{pt} . /$ week was a usual consumption figure for some of the men. The palm wine may contain $2 \cdot 3-5 \cdot 1 \%$

* Sado is the local name for the shrub Rhamnus tsaddo.

+ Caloes are large earthenware pots.

$\ddagger$ e.g. the black plum (Vitex cienkowskii Kotschef \& Peyr and $V$. grandiflora Gürke); West African ebony (Diospyros mespiliformis Hochst.); Lannea acida A. Rich; desert date (Balanites agyptica Del.) (Irvine, I948).

$\S$ e.g. oil palm (Elaeis guineensis Jacq.) rhun or fan palm (Borassus athiopum Mart.); the Raphia palms; and Hyphoaena crinita Gaertn. 
alcohol after 7 days' fermentation (Dalziel, r 937). Heard (1955) has found that after 2-4 days, the wine from fermented sap of Hyphaene crinita contains $3 \%$ yeast (by volume) i.e. about $4 \mathrm{~g}$ yeast protein/l.; this product also contains $4 \mathrm{mg} / \mathrm{l}$. nicotinic acid and $0.2 \mathrm{mg} / \mathrm{l}$. riboflavin. A West African palm wine is reported to contain I45 $\mathrm{mg}$ ascorbic acid/100 g (Bergouniou, I95 I).

So far as I know, the alcoholic contents of fermented milk drinks of Africa have not been reported; by analogy with similar preparations from other countries they would be expected to have about $\mathrm{I}-2 \%$ alcohol strength. However, fermented milk from Turkestan (busa) contains up to $7 \%$ alcohol by weight (Tanner, 1944). Barth (1890) in his journeyings across and immediately south of the Sahara was several times being served with fura or ghussub; this dish is made from millet flour, mixed with water and dry powdered cheese and is often the sole means of sustenance of a Tuareg (Rodd, I926). Leben is an Egyptian product similar to kefir of the Balkans and is made from buffalo's, goat's or cow's milk (Tanner, 1944). Fermented milks or milk products were used by the Zulus (Bryant, I939) and by other Bantu peoples (Fox, I939). It would seem that, according to Nicholls, Nimalasuriya \& de Silva (1939) fermented milk might be a 'safe' food in communities in which sanitation is primitive. In this connexion it is noteworthy that fermented-milk preparations were fed to Bantu infants in the South, and the Masai of Kenya weaned their children on fermented milk.

The commonest alcoholic beverage in Africa is a kind of beer. The process of Kaffir beer-making was outlined and its nutritive value was discussed in a paper presented to this Society by Platt \& Webb (1946). (See also Fox, I938.) Various materials-sorghum, maize, millets, cassava flour with additions of cereals, and plantains are used in the preparation of these beers. There are, as a visitor in the early I 8 th century remarked about beers in this country 'a hundred and a hundred sorts' of beer. This is, I think, the point at which to stress the difference between what we understand by such beverages as Kaffir beer and modern English beer. In England beer was not known until the early part of the I6th century-it was regarded then as a 'Dutch boorish Liquor'; it came with 'Hops and Heresies', a 'sawcy intruder in this land'. Its forerunner, the old English ale, was-at least in its earlier days - a crude cereal product, made from barley, wheat or oats, was brewed in almost every home, and probably more nearly resembled African beer. It is interesting to note that by the $I 7^{\text {th }}$ century 'the Citie calls for Beere' but 'Ale, like a lord of the Soyle, In the Countrey shall domineere' (Halliwell, I630).

The social aspects of the consumption of alcohol are of no less interest in Africa than in this country. There is no doubt that, as one traveller (du Chaillu, I945) put it nearly a century ago: 'men drink because they love to get drunk'; the women, although much more temperate, also get drunk sometimes. Socially and ritually, to the Nandi for example, their beer (maiyek) is important:

'The European who sees a Nandi continually getting drunk although he is at the same time short of food, does not realize that beer is a social necessity and not merely an enjoyment. If a Nandi cannot from time to time give a beer party, even a small party, he will lose social standing; he will be considered 
mean and will not be asked by his neighbours to partake of beer. He will be, unofficially but none the less effectively, pushed out of his rightful place in the social life of the koret (parish)' (Huntingford, 1950).

Beer drinking is, in the words of another observer (Richards, 1939a)

'the people's only kind of entertainment, the chief break in the monotony of their village life, and, as in most other Bantu societies, the common, and sometimes essential way of fulfilling social obligations .... It [beer] is carried to chiefs as tribute, used to reward labour, or given as an offering to spirits .... Abundance of beer is the glory of a commoner's hospitality, or a chief's court. Without it tribal councils cannot be held, and marriage or initiation ceremonies do not take place'.

The quantities of beer brewed for pleasure, for social occasions, for sale and for work in three Nyasaland villages in a year beginning November 1938 are shown in Fig. I. The populations of the hill, foothill and lakeshore villages were ${ }_{15} 6$,

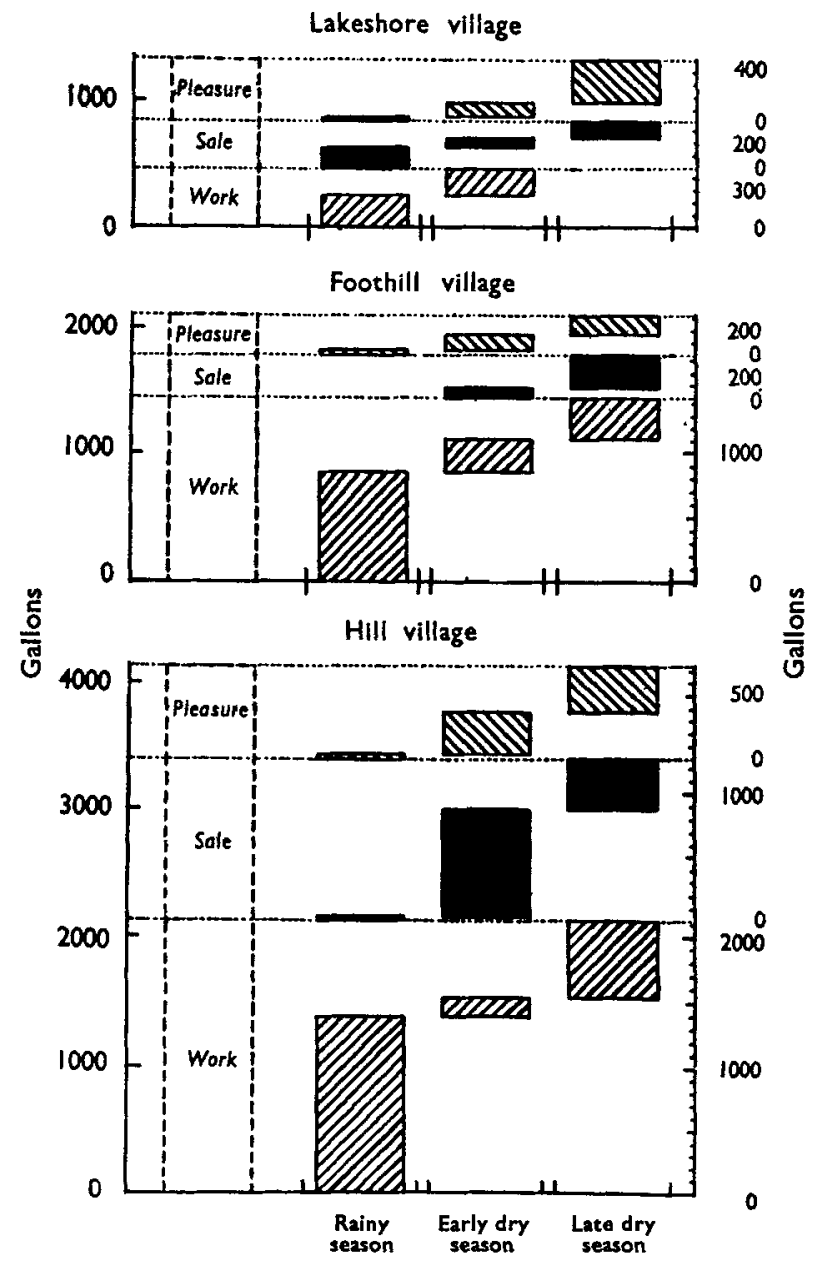

Fig. 1. Annual and seasonal quantities of beer brewed for work, for sale and for pleasure in three Nyasaland villages (Platt, unpublished). 
I07 and I0I respectively. It will be seen that in the rainy season by far the most important occasion for brewing beer is for 'work'.

Collective work is a remarkable feature of many of the less sophisticated communities in Africa; it is the outcome of a sense of duty engendered by a community spirit. It is 'cemented' by beer and regulated by fear of sanctions which are applied in cases of default. The beer party is the usual form in which this collective effort is made, and these parties are chiefly engaged on operations which must be completed (mainly for climatic reasons) within a limited time; for example, the preparation of a garden for planting, or the weeding of grain crops. The liking for beer and its effects on the body ensure a measure of cohesion and application to whatever task is in hand but at the same time the work is carried out superficially and somewhat carelessly, both these characteristics being recognized by the African as necessary evils of the system. In spite of their disadvantages, the speed of work and endurance which characterize the beer parties result in a far greater acreage being covered in a day than can be achieved by the same number of men and women working separately in their own gardens. The importance of assistance to the 'occupiers' of land is shown in Fig. 2 in which the proportion of total labour expended on agricultural work by hands other than those of the occupier is shown

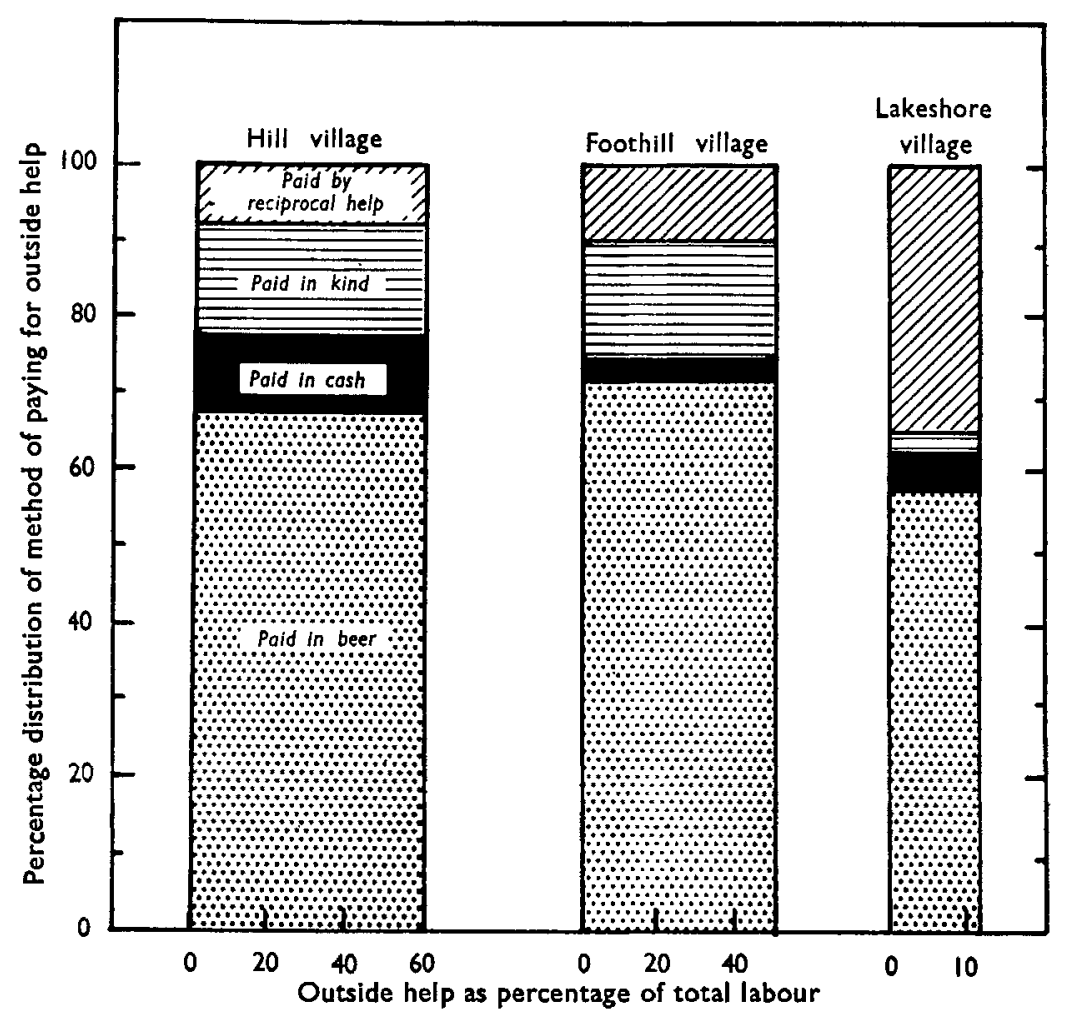

Fig. 2. The dependence on outside help and the method of paying for this labour in three Nyasaland villages (Platt, unpublished). 
as 'outside help'; the method of payment is expressed in terms of the percentage of this help paid for with beer, cash, 'in kind' or by reciprocated work.

The traditional role of beer is most strongly marked in the hill village, less so in the foothill village and least marked in the lakeshore village. This order of diminishing importance of beer is also the order of increasing influence of the European, through the effects of the Christian missions, the development of a mercenary attitude in village life and the absence of men 'abroad'-working in mines or on plantations.

In so far then as the total food production in a village may be affected by the amount of collective work done for beer (or, in other places, for palm wine) there is a direct relationship between nutrition and drinking. Another quantitative aspect of the production of alcoholic beverages, particularly those made from staple cereals or other staple foods such as plantain and cassava, is an obvious one: that, to the extent that these materials are used in the brewing of beer, they cannot be employed for making porridge and other dishes. Unquestionably, large quantities of grain grown in Africa are employed in the preparation of beers. For example, it has been estimated that of the sorghum produced in the Logone Plains, onethird is eaten, one-third is consumed as beer, and one-third is destroyed by the passage of elephants through the crop or by bush fires (Hardy \& Richet, 1933); that is to say, half the harvested crop is consumed as beer. Two identical estimates of one-sixth of the grain produced being converted into beer have been given for the Bemba in Northern Rhodesia (Richards, $1939 b$ ) and for the Nandi in Kenya (Huntingford, 1950). Measurements in three Nyasaland villages gave a rather lower value for the proportion of grain consumed as beer (Platt, unpublished). In the hill village, where most beer was brewed, about one-eighth of the crop was consumed in this form. It has been estimated that in England in the Middle Ages as much as a third of the grain crop went into the brewing of ale (Maitland, 192 I).

There have been from time to time complaints by officials and others about African beer-making, which appeared to them to be a great and unjustifiable waste of food, particularly when grain supplies were short. It is, of course, important to know whether any appreciable losses occur in brewing, particularly with those people whose food economy is at a bare subsistence level. There are two sources of loss: (1) in the conversion of carbohydrate to alcohol during fermentation, and (2) as alcohol excreted by the individual after consuming the beverage. The loss during fermentation is theoretically rather less than $3 \%$. From what we now know of the disposal of alcohol, the major portion of alcohol undergoes oxidation, while only a small amount is excreted directly through the kidneys, lungs and sweat glands. The amount excreted by these routes is as a rule only a very small fraction of the total disposal. Although increase of excretion may occur when the total intake is excessive, nevertheless even when consumption is high the proportion of ingested alcohol excreted by such means remains small. The total intake of alcohol 
in the course of African beer parties of the traditional kind may be quite substantial*, but it is consumed over a comparatively long period of time and, from the nature of the brew, is taken with considerable amounts of carbohydrate, protein and other products of breakdown of the grain. The intervals between drinks in the course of a working beer party may be as long as $3 \mathrm{~h}$. There is some evidence, not, however, conclusive, that alcohol is used up during exercise more rapidly than nutrients which ordinarily supply energy. The form and manner therefore in which traditional alcoholic beverages are drunk by the African tend to the maintenance of a sustained but comparatively low concentration of alcohol in the blood, and it would seem therefore that on physiological grounds good utilization of alcohol from African beers might be expected.

Against the small loss of energy there must be set certain advantages derived from the process which goes on in the beer pot; this we have called 'biological ennoblement' (Platt \& Webb, 1946). The contribution of this process to the nutritional value of the beer includes the products of germination of such 'malted' grain as is used in making the beer, and the substances accruing from microbiological growth including yeasts. Ascorbic acid, several B-vitamins and proteins (microbial) are the main nutrients derived from the fermentation and some at least of these, especially at certain times of the year, are likely to be of considerable value in maintaining the health of the consumer. It seems likely also that the assimilability of the ingredients, particularly of complex carbohydrates, is increased as a result of brewing. Even an infant may benefit nutritionally as not infrequently he is given the beer dregs from the previous night's party; he is hardly likely to become alcoholic from this supplement to his diet for the practice is, so to speak, to wash the dregs by decantation towards the end of the drink.

Thomas Sydenham, who practised in London in the middle of the $I$ th century, constantly prescribed small beer for his patients, being, no doubt justifiably, suspicious of the London drinking water. Possibly for a similar reason children in this country were regularly given small beer. Records from different parts of Africa show that men will rarely drink anything but beer. The Bahaya, for example, when faced with a temporary dearth of beer, will drink unfermented banana juice and also some kinds of cooking water, but they take every precaution to avoid this necessity and believe that too much of the unfermented juice would ruin their potency. They do, it seems, succeed in avoiding attacks of dysentery (Culwick \& Culwick, 1939).

A good deal of research remains to be done on indigenous beverages, the results of which might well be of general interest as well as of immediate benefit to the African. Among the subjects suggested for further investigation in the First Report

* In three Nyasaland villages (1938-9) the consumption of beer was 212,407 and $52 \mathrm{ml}$./head/day for hill, foothill and lakeshore villages respectively. Seven men observed for periods of I week during December to March (the rainy season) derived $35 \%$ of the energy value of their food from beer (mowa) i.e. $10.6 \%$ from alcohol, taking $3 \mathrm{~g}$ alcohol $/ 100 \mathrm{ml}$. beer. During January 1939 on 15 days in which work was done in the fields, a total of 1223.5 pt. of mowa was consumed in 119 'man-days' i.e. an average of r0.25 pt. of mowa/man/working day. The alcohol for this amount of mowa is about $215 \mathrm{ml}$. Removal of this amount at the rate of $7 \cdot$ I ml/h (Mellanby, 1919) would require about $30 \mathrm{~h}$. Beer parties were held on only half the days in the month, and there was almost always I day between two parties. 
of the WHO Expert Committee on Alcohol (World Health Organization: Expert Committee on Alcohol, 1954) are two which might with advantage be investigated in some African communities. The first of these is the phenomenon of craving, which was recognized many years ago in the Bantu of South Africa (Junod, 1927). Beer drinking being as old as the tribe itself and perhaps as ancient as the introduction of cereals, the phenomenon is said to be by no means the result of civilization (Junod, 1927). Another and more recent comment (Richards, 1939c) is that old men who have been accustomed to drinking beer say that they 'feel their stomachs asking for it'. An interesting and possibly not unrelated phenomenon recognized throughout inter-tropical Africa is a craving for meat.

The other subject which might be considered for research arises out of the formation of acetate in the course of alcohol metabolism. We know also that the acetate molecule enters into the synthesis of cholesterol (Little \& Bloch, 1950) and it might well be worth while following up this in the study of those degenerative diseases which are thought to involve disordered cholesterol metabolism. It is of special interest in this connexion that in parts of Africa the influence of Islam has been profound and that the misuse of alcohol has at least diminished and in some areas has disappeared.

Although I have been primarily concerned with traditional African beverages, I want to draw attention briefly to various ways in which the sophistication of alcoholic beverages and the substitution for traditional beverages of more potent liquors, distilled spirits, has occurred*. One way of increasing the potency of a brew practised in some areas, is double fermentation. When the first fermentation is nearing completion the brew is heated and a further batch of malted grain is added. An obvious way is to add readily fermentable material, e.g. honey (cf. 'honeyed ale'), sugar, sugar-cane juice. One type of strong drink is prepared from Golden Syrup bought from the stores; a large quantity of tins of this harmless 'missionary jam', as it is called in South Africa, imported into Johannesburg is used not by missionaries but by natives of the compounds, who brew a strong drink in large empty oil cans. Distillation has been introduced and many fermented preparations such as of cane juice, cassava, plantain, honey, and various fruits, e.g. those of the so-called 'brandy bush', Grewia flava, (Burchell, I953) have been used for making spirits. Generally the practice is outlawed and it would be a pity if strong alcoholic drinks were allowed to displace the traditional preparations which, in moderation, have desirable features, many of them nutritional.

Alcoholism is indeed not a new problem in Africa. On a journey up the Niger a traveller (Thomson, 1887 ) found on the lower river 'luxuriated in congenial union fetishism, cannibalism and the gin trade'. Further up the river he says 'I observed an ever-increasing improvement in the appearance and character of the native, cannibalism disappeared, fetishism followed in its wake, the gin trade largely

* Nicol (195 ) records a consumption of $107 \mathrm{ml}$. of illicit gin per head per day for families of Soragbemi fishermen (ten males and thirteen females) in Southern Nigeria. The average alcohol content of locally distilled spirits was $60 \%$. This quantity was in addition to $103 \mathrm{ml}$. per head per day of palm wine consumed. 
disappeared'-owing to Mohammedanism. On the other hand we may concur with a reverend gentleman writing nearly 50 years ago (Bryant, I939):

'It is a great error, in my opinion, to assume, as many, even "Old Colonists", are apt to do, that this Kaffir-beer is simply and solely an intoxicating drink. It is, in my view, much more than a luxurious and supererogatory beverage. It is rather a very admirable, very beneficial, even, perhaps, very necessary, form of food; and Governments in their legislation thereanent should recognize this fact, and aim rather at preventing its abuse than preventing its use'.

\section{REFERENCES}

Barth, H. (1890). Travels and Discoveries in North and Central Africa, p. 183. London: Ward Lock \& Co. Beckingham, C. F. \& Huntingford, G. W. B. (r954). Some Records of Ethiopia, p. 64. London: Hakluyt Society.

Bergouniou, J. L. (I95I). Probleme Alimentaire et Nutritionnel. Dakar: Mission Anthropologique de l'A.O.F.

Bryant, A. T. (1939). A Description of Native Foodstuffs and their Preparation, p. 9. Pretoria: Government Printer.

Burchell, W. J. (1953). Travels in the Interior of Southern Africa, Vol. 1, p. 254. London: Batchworth Press.

Culwick, A. T. \& Culwick, G. M. (1939). Unpublished report.

Dalziel, J. M. (1937). The Useful Plants of West Tropical Africa, p. 506. London: Crown Agents for the Colonies.

du Chaillu, P. B. (1945). Exploration and Adventures in Equatorial Africa, p. 444. London: Werner Laurie \& Co.

Earthy, E. D. (1933). Valenge Women, p. 43. London: Oxford University Press.

Fox, F. W. (1938). F. S. Afr. chem. Inst. 21, 39.

Fox, F. W. (1939). Bantu Stud. March, p. 65.

Greenway, P. J. (1945-6). E. Afr. agric. F. 11, 56.

Halliwell (1630). Quoted by D. Hartley in Food in England, p. 546. London: MacDonald.

Hardy, G. \& Richet, C. (1933). L'Alimentation Indigene dans les Colonies Franfaises. Paris: Vigot Frères.

Heard, C. R. C. (1955). Proc. Nutr. Soc. 14, xi.

Huntingford, G. W. B. (1950). Colonial Research Studies, no. 4. p. 70. London: H.M. Stationery Office.

Irvine, F. R. (1948). The New York Botanical Garden, 49, 267.

Junod, H. A. (1927). The Life of a South African Tribe, p. 42. London: Macmillan.

Little, H. N. \& Bloch, K. (1950). F. biol. Chem. 183, 33.

Maitland, F. W. (1921). Quoted by E. C. Curwen (1946) in Plough and Pasture, p. 76. London: Cobbett Press.

Mboto, I. (1933). Niger. Fld, 2, no. 6, p. 40.

Mellanby, E. (1919). Spec. Rep. Ser. med Res. Coun., Lond., no. 31, p. 12.

Monod, T., da Mota, A. T. \& Mauny, R. (I95I). Description de la Cóte Occidentale d'Afrique (Senegal au Cap de Monte, Archipels) par Valentim Fernandes (1506-1510). Bissau: Centro de Estudos da Guiné Portuguesa.

Nicholls, L., Nimalasuriya, A. \& de Silva, R. (1939). Ceylon J. Sci. D, 5, 17.

Nicol, B. M. (1952). Brit. $\mathcal{F}$. Nutr. 6, 34.

Platt, B. S. \& Webb, R. A. (1946). Proc. Nutr. Soc. 4, I31.

Renard, G. (1929). Life and Work in Prehistoric Times, p. 34. London: Kegan, Paul, Trench, Trubner $\& \mathrm{Co}$.

Richards, A. I. (1939a). Land, Labour and Diet in Northern Rhodesia, p. 76. London: Oxford University Press.

Richards, A. I. (1939b). Land, Labour and Diet in Northern Rhodesia, p. 80. London: Oxford University Press.

Richards, A. I. (1939c). Land, Labour and Diet in Northern Rhodesia, p. 59. London: Oxford University Press.

Rodd, F. R. (1926). People of the Veil, p. I57. London: Macmillan \& Co.

Seyffert, G. (1930). Quoted by F. S. Bodenheimer (1951) in Insects as Human Food, p. I69. The Hague: W. Junk. .

Tanner, F. W. (1944). The Microbiology of Foods, and ed. Illinois: Garrard Press. 
Thomson, J. (1887). F. R, anthrop. Inst. x6, I82.

Vavilov, N. I. (1931). Address to the 2nd International Congress on History of Science and Technology.

Walters, J. H. \& Smith, D. A. (1952). W. Afr. med. F. (N.S.) I, 2 I.

World Health Organization: Expert Committee on Alcohol (1954). Tech. Rep. Wld Hlth Org. no. 84.

\section{Alcohol in Intravenous Feeding}

\section{By A. W. Wilkinson, Surgery Department, University of Aberdeen}

Some degree of starvation is a common and accepted sequel to severe injury, and for several days after major operations patients usually lose their appetite and do not eat. In the past attempts have been made to avoid this period of starvation by means of intravenous feeding with protein hydrolysates and various sources of energy. Close examination of the normal response to injury shows, however, that the well-nourished patient has an inherent capacity to survive injury and starvation and to heal his wounds, that after injury the organism so orders its economy that it provides from its own substance the raw materials for the repair of injured tissues as well as the daily energy requirements. The present tendency is thus once more to leave the body as much as possible to its own rather inscrutable devices during the postoperative period. This attitude means that the potential field for intravenous feeding, including the administration of alcohol, has again contracted to the few states in which a patient is unable to ingest or digest food by the alimentary tract.

The value of parenteral nutrition is rather uncertain but there may be some place for it in the treatment of patients with fistulas of the small intestine, ulcerative colitis, advanced malnutrition and some forms of hepatic disease. Originally a 5 or $6 \%$ solution of amino-acids derived from the acid or enzymic hydrolysis of milk protein was combined with a source of energy such as glucose. The success of intravenous feeding with protein depends, however, on the provision of an adequate accompaniment of calories, which has given rise to most practical difficulties.

An uninjured healthy person lying in bed probably requires about $2100 \mathrm{Cal} /$ /day, but this basal requirement is increased after injury and by other forms of inflammation (Cuthbertson, 1945). To supply $2100 \mathrm{Cal}$. would entail the daily infusion of over II 1 . of $5 \%$, or 5.61 . of $10 \%$, glucose solution. Even normal subjects have only a limited tolerance for repeated large intravenous infusions; after injury and in inflammation of all kinds this tolerance is greatly reduced and, apart from the replacement of losses of body fluids, not more than $2.5 \mathrm{l}$./day can be safely administered. Emulsions containing up to $30 \%$ of fat have been developed and administered intravenously and are safe and satisfactory sources of calories but have a limited stability or 'shelf-life'. A I $5 \%$ fat emulsion would provide 1200 Cal./l. but, unfortunately, is still not commercially available. These various difficulties in providing adequate supplies of energy to accompany or 'cover' infusions of protein 